\title{
A Cabinet of Curiosities
}

\section{Ricarda Wagner \\ Introduction: In Excess}

Before scholars programmed databases to make visible and accessible the minute details of their research to peers and grant-giving agencies, amassing and exhibiting a wide array of material things in order to show one's comprehension of the world was a well-established practice in late sixteenth- and seventeenth-century Europe. Men of letters and science established awe-inspiring personal collections encompassing a bewildering variety of objects that were housed in "cabinets of curiosities" or Wunderkammern. Some of these material things were natural specimens, such as the dinosaur bones in the possession of the Danish polymath Ole Worm. Others were extraordinary artefacts that displayed human ingenuity, like automata, for example, or promised mystical insight, such as the Egyptian obelisks collected by the Jesuit Athanasius Kircher. ${ }^{1}$ Others, still, displayed evidence of the preternatural in the form of unicorn horns or the remains of monstrous births.

The first major cabinets were born of a happy eclecticism, a wild urge to collect all manner of oddities, which were then displayed haphazardly, leaving it to the onlooker to find connections between an insect enclosed in amber and a Mayan mask. Later collectors, influenced by new developments in taxonomy and the increasing differentiation of knowledge into separate fields, instead preferred a more organised approach that properly classified objects and established relations between standard and eccentric exhibits. ${ }^{2}$ Rather than following this approach that collects as a way of ordering the world, our literary Wunderkammer reaches back to the early cabinets and their antiquarian inclinations that focussed on the weird, seeking out those objects that inspired curiosity and awe, impulses that shake our sense of mastery over the material world. While the rest of this volume strives to establish a coherence, cataloguing inscribed artefacts according to their geographical provenance, function and material substance, here we offer a small miscellany of singular things that resist our taxonomies. One of a kind, they represent not all the world of medieval literary inscriptions, but some of its most eccentric manifestations: an inscribed horse, a speaking ship that sails across time, etchings on an apple, a diamond dog leash, a crystal altar-as-bed, a magical message-bearing chair, and the legendary Holy Grail. These objects epitomise what Lorraine Daston refers to as "talkative things":

1 Cf. Kohl 2003, 236f. Pomian 1990 offers a comprehensive history of the cabinet of curiosities from 1500 to 1800 .

2 Macdonald 2006, 84 locates this turn in the seventeenth century, while Kohl 2003, 241-244 focusses on the eighteenth century.

๑ Open Access. (c) 2019 Ricarda Wagner, Michael R. Ott, Christine Neufeld, Maria Krümpelmann, Tamara Ludwig and Ludger Lieb, published by De Gruyter. (cc) BY-NC-ND This work is licensed under the Creative Commons Attribution-NonCommercial-NoDerivatives 4.0 License. https://doi.org/10.1515/9783110645446-017 
"Talkative things instantiate novelty, previously unthinkable combinations. Their thingness lends a vivacity and reality to new constellations of experience that break old molds [...] [T] he new thing becomes a magnet for intense interest, a paradox incarnate. It is richly evocative; it is eloquent". ${ }^{3}$

We offer this collection of eloquent things as an appendix to our volume that, like the early modern cabinets of curiosities, explored the intersections between textual culture and material experience. ${ }^{4}$ As Derridean supplements to our classifications of many inscribed objects familiar because of their ubiquity, these particular talkative things incite estrangement, reminding us that in the end things exceed the stories we tell about them, reaching beyond pen and parchment.

\section{Michael R. Ott}

\section{Equine écriture}

The story of Floris and Blancheflour, well known in several medieval vernaculars, is not only a story about love, youth, and nobility, but also a tale of precious and potent things. As far as the German version by Konrad Fleck (c.1220) is concerned, one of these things is actually an animal. When Flore departs from his royal parents and homeland to search for his beloved Blanscheflur, he is equipped with a unique horse. This horse is perfect in every respect, and it is delightfully (and naturally) coloured: its coat is white on one side and red on the other, with a pitch-black line in between that is three fingers broad, starting at the horse's forehead, traversing its back, and ending in a tail in which, according to the narrator, nature has mixed the colours red and white.

Of course, there is more to this horse than its colouring. Chivalric culture is strongly entangled with horses; the audience of courtly literature certainly knew a lot about them and, justifiably, expected equine nuance. Indeed, the subsequent description of Flore's horse goes into some detail, exceeding today's common knowledge about horses and related terminology. But what makes for a rather excessive description today certainly met the expectations and expertise of thirteenth-century readers and listeners. The horse's head (houbet, 2758), so we are told, was small, its legs (gebeine, 2760) were strong, its pastern upright (hôhevizzelîchen fuoz, 2761), its ribcage (bruste, 2766) solid, its flanks (lanken, 2767) adequately thin, and its haunches (goffen, 2768) round. And "it was as much faster than the other horses as it was more beautiful” (er was vor den andern snel / als vil als er schœener was, 2770f.). ${ }^{5}$

3 Daston 2004, 24.

4 Cf. Zytaruk 2011, 2f. for an analysis of the paradoxes that position the early cabinets between different epistemologies.

5 See Fleck 1846. All translations are mine. 
Since this horse is obviously a marvel of nature, it is hard to imagine how any artifice could further increase its quality and excellence. The text's answer to this challenge is to present writing as a natural phenomenon:

\author{
nû hœrent wunder, man las \\ geschriben an sînen siten \\ 'mich sol niemen rîten \\ wan der wert sî der krône. \\ das was von nâtûre schône \\ entworfen âne mannes list. \\ (2772-2777)
}

\begin{abstract}
Listen to marvels now! One could read, written onto his flank: "nobody may ride on me but he who his worthy of the crown". This was by nature beautifully fashioned without men's skilful action.
\end{abstract}

Letters on the flank of a horse, written without human agency, are wondrous enough. But the entanglement of nature and culture does not end with this marvel. Letters written on animal skin indicate a manuscript culture that also aims to communicate. The inscription does not merely decorate the already impressive horse; nor does the message relate only to the animal. The inscription on Flore's lettered horse transforms the animal itself into a test, ultimately restricting the entanglement of horse and rider to just one person. The perfect horse is not just given to Flore, it is made for him, and the inscription prescribes this association between the hero and his new steed. After all, Floris's power and nobility are not purely man-made, the result of personal excellence and heroic deeds, but are also a naturally given fact, published by nature in writing.

\section{Christine Neufeld The Ship of Faith}

Malory's Morte Darthur contains many notable inscriptions, the most remarkable of which is the Ship of Faith in Book 17 of the Tale of Sankgreal, a relatively faithful translation of La Queste del Saint Graal (the fourth branch of the thirteenth-century French Arthurian prose cycle). Here Galahad is reunited with Perceval and Bors, and introduces his fellow knights to his mysterious companion, who reveals herself as Percival's sister. They journey together on a mysterious ship, engraved with "two fayre lettirs wrytten, which seyde a dredefull worde and a mervaylous: 'THOU MAN WHYCH SHALT ENTIR INTO THYS SHIPPE, BEWARE THAT THOU BE IN STEDEFASTE BELEVE, FOR I AM FAYTHE. AND THEREFORE BEWARE HOW THOU ENTIRST BUT IF THOU BE STEDEFASTE, FOR AND THOU FAYLE THEREOF I SHALL NAT HELPE THE. ${ }^{6}$ On board the ship the knights examine an assortment of marvellous

6 Malory 1968, 706. Cf. Ship of Faith episode in La Queste del Saint Graal, 195-280. For an English translation, see Comfort's The Quest of the Holy Grail, 161-225. For Malory's version, see 703-723 in 
objects, including a sword, scabbard and girdle, all bearing inscriptions that far exceed their material capacities. On the poorly made girdle, for instance, we find the following elaborate text:

HE WHYCH SHALL WELDE ME OUGHT TO BE MORE HARDY THAN ONY OTHER, IF HE BEARE ME AS TRULY AS ME OUGHTE TO BE BORNE. FOR THE BODY OF HYM WHICH I OUGHT TO HANGE BY, HE SHALL NAT BE SHAMED IN NO PLACE WHYLE HE YS GURDE WITH THE GURDYLL. NOTHER NEVER NONE BE SO HARDY TO DO AWAY THYS GURDYLL, FOR HIT OUGHT NAT TO BE DONE AWAY BUT BY THE HONDIS OF A MAYDE, AND THAT SHE BE A KYNGIS DOUGHTER AND A QUENYS. AND SHE MUST BE A MAYDE ALL THE DAYES OF HIR LYFF, BOTH IN WYLL AND IN WORKE; AND IF SHE BREKE HIR VIRGINITÉ SHE SHALL DY THE MOSTE VYLAYNES DETH THAT EVER DUD ONY WOMAN.?

From the prosopopoeic vessel personifying Faith to the inscriptions on the sword and its accessories which warn, challenge, prophesise and prompt accounts of past events (with this memorial function creating complex biographies for the artefacts themselves), the Ship of Faith episode is the apotheosis of inscriptionality in Malory.

Interestingly, two thirds of the inscriptions found in Malory cluster around the storylines of Balin le Sauvage and Galahad, plotlines bound together by Balin's sword, which Merlin inscribes and sends to Arthur's court in a red marble stone for Galahad to claim. ${ }^{8}$ These inscriptions function variously according to the categories established in this volume. The many inscribed tombs fixed in the Arthurian landscape rewrite, as Kenneth Tiller argues, the histories of the knights and ladies along the lines of an incipient code of chivalry. ${ }^{9}$ The locomobile inscribed objects-swords and scabbards, as well as furniture like the Siege Perilous-function as object tests that chart narrative trajectories by revealing individual identities, creating relationships, and propelling heroes to their destinies. The Ship of Faith, however, complicates these categories. As a ship, it is locomobile in that it is designed to move through space: its journey from Logris to Sarras transports the Grail knights definitively out of the secular into the sacred realm, just as their embrace of Faith by boarding the vessel transforms them from knights errant to spiritual pilgrims. However, as a ship built by King Solomon containing messages for future generations its persistence through time also gives it the memorial function of locostatic markers designed to anchor individual and communal identity. Its ancient provenance, furthermore, highlights that the inscriptions appearing in the Arthurian world can come from different sources.

Vinaver's edition of the Winchester manuscript. Vinaver's edition highlights inscriptions by using uppercase letters. Interestingly, Malory's relatively faithful translation of his French source omits a fascinating detail: the Queste del Saint Graal specifies that the ship's inscription is written in Chaldean.

7 Malory 1968, 708.

8 See Michael Ott's discussion of this episode in the chapter on weapons in this volume.

9 See Tiller 2004. For more on the French sources see Iris Roebling-Grau's and Sascha A. Schultz' chapter on tombs in this volume. 
Merlin's metafictional role as an author figure through his inscriptions in the Balin episodes is replaced in the Galahad plot by a divine hand writing the destinies of the Grail knights. ${ }^{10}$

The importance of this shift is highlighted in the Ship of Faith episode by the prominence given to the act of inscribing through the portrayal of the origin of the ship's inscriptions. Whereas in some versions of the La Queste del Saint Graal (Bodley Rawl. 814, for example), Solomon only reads the writing on the ship upon waking, Malory's Solomon witnesses the angel inscribing the words into the ship in his dream. The direct citation of the inscription at its moment of creation repeats (in a slight paraphrase) a text Malory's readers have already read, authoritatively linking biblical past and Arthurian present:

THAT nyght lay Solomon before the shippe with litill felyship. And whan he was on slepe hym thought there com from hevyn a grete company of angels, and alight into the ship, and took water whych was brought by an angell, in a vessell of sylver, and besprent all the shippe.

And aftir he came to the swerde, and drew lettirs o[n] the hylte. And aftir wente to the shippebourde, and wrote there other lettirs whych seyde: "THOU MAN THAT WOLTE ENTIR WITHIN ME, BEWARE THAT THOU BE FULLE IN THE FAYTHE, FOR I NE AM BUT FAYTH AND BELYVE".

Whan Salamon aspyed thos lettirs he was abaysshed, that he durst not entir, and so drew hym abacke; and the shippe was anon shovyn in the see. He wente so faste that he had loste syght of him within a litill whyle. And than a voyce seyde:

"Solomon, the laste knyght of thy kynred shall reste in thys bedde". ${ }^{11}$

This is the only moment in the Morte Darthur when our attention is drawn to the act of inscription itself. Merlin's inscriptions, as Kathy Cawsey has observed, function more as magical writing in which the technical act itself remains obscured. ${ }^{12}$

Malory's focalization of the act of inscription in Solomon's dream recalls a similar episode in the apocryphal Vita Adae et Evae. Esther Quinn has already related this legendary material to the Queste in her examination of the rood-tree legend that informs the other significant (though uninscribed) artefacts, the bed and spindles, on the ship. ${ }^{13}$ I propose that there is another aspect of the legend at play in the Ship of Faith episode. In the apocryphal legend Solomon also dreams about an act of inscription: the two tablets of clay and stone on which, at Eve's command, Seth inscribed the lives of the first parents, his hand guided by an angel. ${ }^{14}$ Solomon's dream about an angel inscribing the ship thus invites Malory's audience to recall the first inscribed objects of cosmic history, a divinely sanctioned missive whose material perdurance manifests

10 See Cawsey 2001, 90.

11 Malory 1968, $713 \mathrm{f}$.

12 Cawsey 2001, 90.

13 Quinn 1965, $194 \mathrm{f}$.

14 See discussions of this material in Christine Neufeld's and Ricarda Wagner's chapter on British literature and Sascha A. Schultz' chapter on stone in this volume. 
the possibility of grace. In Galahad, the last of Solomon's lineage and achiever of the Grail, the story begun by Seth's account of the Fall-humanity's quest for reconciliation with the divine-is accomplished, if only on an individual level. For those left behind, the destiny inscribed into the landscape remains much more ambiguous; for the remaining inscriptions' authorship is neither attributed to Merlin's political orchestrations, nor clearly a divine intervention. This would not be so perturbing, given how few inscriptions follow the Ship of Faith, if it were not for the fact that it renders even more mysterious the most famous Arthurian inscription of all, along with the figure whose destiny it portends: HIC IACET ARTHURUS, REX QUONDAM REXQUE FUTURUS. ${ }^{15}$

\section{Michael R. Ott}

\section{The Apple of Discord}

Are inscriptions gendered? Of course, they do not have a gender themselves, but are they concerned with gender categories and do they interact with them? In search of an answer we may turn to the "Apple of Discord", an extraordinary script-bearing artefact with a long tradition. The basic story is well known and easy to retell: Jupiter invites all the gods and goddesses to the wedding of his sister Thetis and the Greek prince Peleus. Only one goddess, Discordia, the goddess of discord, receives no invitation. In order to take revenge, Discordia approaches the wedding ceremony invisibly and throws an apple between three distinguished attendees: Juno, goddess of power, Pallas, goddess of wisdom, and Venus, the goddess of love.

At least, this is how Konrad von Würzburg describes the matter in his unfinished Trojan War, written in the late 13th century. Konrad also describes Discordia's apple in some detail, revealing an extraordinary script-bearing artefact that cannot easily be compared to more realistic inscribed items, such as weapons, tombs, walls, or tablets. Observed closely, the apple sparkles to such an extent that no single colour can be fully captured visually-though all colours are there, as the narrator is eager to explain. Looking at it from a distance, the apple appears to consist of two amalgamated halves, one made of gold and the other made of silver. At the intersection of these two halves is a green circlet, one finger wide, made of tiny emeralds. This circlet bears writing, crafted out of many-coloured pearls, which always appears in the language of the particular reader. The inscriptions on the circlet says: 
swelch frouwe sî noch hiute

diu schœnste ûf disem veste, sô daz an ir kein breste, noch kein wandel werde schîn, der eigen sol der apfel sîn, noch anders keines wîbes. ir muotes und ir lîbes muoz si wesen $\hat{u} z$ erwelt und für die besten sîn gezelt, diu von der hôchgezîte spil mit ir den apfel füeren wil.

(1454-1464)
The lady who today, at this celebration, is the fairest, showing no deficiency and no fickleness, to her the apple shall belong-and to no other woman. Regarding her attitude and her appearance she who likes to take the apple with her has to be excellent and she has to rank among the best. ${ }^{16}$

After reading the inscription, every one of the three goddesses lays claim to the apple. Although the inscription's semantic sense would likely instigate a fight, it is not just the text and its message that cause discord. The inscription, the narrator explains, is also a spell, causing each reader, regardless of her initial disposition, to estimate herself to be the fairest and most illustrious. This leads to an even more serious conflict. If the inscription induces a contest, the enchantment turns this contest into an inextricable situation.

The subsequent story line is equally well known: the three women have a heated argument and turn to Jupiter for help. Jupiter, however, shuns the conflict and the decision and turns to Paris, a nearby shepherd, renowned for his impartial and just rulings. Eventually, Paris awards the apple to Venus-and much havoc ensues.

The disastrous apple and its inscription are gendered for at least two reasons. First of all, it divides characters according to their gender: women on the one hand and men on the other. Indeed, Jupiter and Paris show absolutely no interest in owning the apple. Both of them are only concerned with a solution to the dispute. This is because, second, the inscription is explicitly directed at women alone and also determines important aspects of femininity: beauty and good behaviour. And the magic spell ensures that the goddesses, and not the surrounding men, keep to these standards-standards that, in the first place, are intended to cause conflict and chaos. That is why the inscription on the Apple of Discord can be said to be gendered.

16 Konrad von Würzburg 1858. The translation is mine. 


\section{Michael R. Ott}

\section{The Diamond Dog Leash}

Wolfram von Eschenbach's Titurel, written around the year 1220, is exceptional for several reasons. First of all, we know of no source Wolfram has adapted. This is noteworthy because Wolfram's other epic texts, his Parzival and his Willehalm, rely, like most German courtly literature of this time, on French sources, albeit in a very autonomous and creative way. The second peculiarity is linked to the first: Wolfram's Titurel picks up minor characters from Parzival and gives them a back-story, very much like Tom Stoppard's play Rosencrantz and Guildenstern Are Dead expands on Hamlet. Actually, Wolfram von Eschenbach is working on a "story world", and others follow his lead, like Albrecht von Scharfenberg with his so-called Younger Titurel, written about half a century after Wolfram's text. These two distinct features already mark Titurel as an experiment; and this perception also matches the form, because the text is written in complex stanzas invented for this very poem. It is not surprising considering its status as an experiment that only two fragments of Titurel survived. Even though we do not know for sure, it is perfectly possible that Wolfram never wrote more than these two fragments.

We are most interested in the second of the two fragments, which focuses on a young girl and a young boy who are about to learn what love is. The young man with the fancy name Schionatulander catches a run-away hunting dog. We know for a fact that historically these dogs typically had long leashes. But this particular leash is special. It is "a good twelve fathoms long, the braid-silk of four colours [...] ornamentally wrought together" ${ }^{17}$ When the silk leash is unfolded, "script could be perceived on it, on the outside and the inside", with letters "of emerald, mingled with rubies" as well as "diamonds, chrysolites and garnets". ${ }^{18}$

While the girl Sigune begins reading, the narrator explains that "the leash had been sent to a prince for reasons of love"19 as a gift and love letter with its own transportation device. This animal 'device' went astray, following the blood trail of a wounded animal. To keep hold of the hound, Schionatulander fixes the leash to the pole of a tent. Sigune, however, wants to read the letter to the end and so she unknots the leash only to have the hound run away again. In her attempt to detain the animal Sigune cuts her hand. Deeply affected by the text, Sigune promises Schionatulander her love on the condition that he brings the leash back to her. Although

17 All translations by Edwards 2004. The German text reads: daz seil was wol zwelf klâfter lanc, die von vier varwe bortesîden wâren, [...] an ein ander geworht mit gezierde (Wolfram von Eschenbach 2003, 144,2-4).

18 zwischen den ringen, ûzen unt innen kôs man dran schrift [...]. Smaragede wâren die buochstabe, mit rubînen verbundet. adamant, krisolîte, grânât dâ stuonden (Wolfram von Eschenbach 2003, 146,1147,2).

19 daz seil einem fürsten durch minne wart gesant (Wolfram von Eschenbach 2003, 151,1f.). 
Schionatulander tries, he dies soon afterwards when he is confronted by a knight in the forest. However, we only learn of this fatal outcome in Parzival when the young hero encounters Sigune cradling the dead body of Schionatulander like a Pietà.

Fashioning a leash as a script-bearing artefact is exceptional, especially a leash so beautiful and costly. But the fascination of the second fragment stems not only from the artefact and its materiality but from how it stages and reflects the complexities of communication, writing, and reading. The extent of this complexity becomes apparent, for example, when readers learn that the hound got away from the message's recipient that same day and that the content of the communiqué closely mirrors the situation of Sigune and Schionatulander. The materiality of this text is compounded by its entanglement with the world of the animal. Moreover, this is a text that makes itself felt; it wounds Sigune, mingling her blood with that of the prey scented by the hound in the mind of the audience. This complex interlocking of the characters' fates, in connection with an intricate narrative and an extraordinary artefact offers a profound reflection on textuality, unique for its time.

\section{Michael R. Ott \\ The Crystal Bed}

The "cave of lovers" (Minnegrotte) in Gottfried von Straßburg's Tristan and Iseult is one of the most iconic scenes in a story that certainly does not lack memorable sequences. What makes it stand out from other scenes is its status as an extensive allegory, followed, moreover, by the narrator's allegorical interpretation- "the first explicit allegorical exegesis performed in German secular poetry", as Haiko Wandhoff reminds us. ${ }^{20}$ Not surprisingly, the cave has been discussed in detail by numerous scholars, "leading to the well-established notion that in it is buried the key to a proper understanding of the entire romance". ${ }^{21}$ Yet, many have overlooked-or only mentioned in passing - the rather inconspicuous inscription on the crystal bed that Tristan and Iseult share during their pleasant exile. This bed signifies, the narrator explains, the transparency of love.

To be sure, there are few inscriptions in Gottfried's work and so one might easily overlook this one. But since the bed and its inscription constitute the very centre of the cave, we may want to treat the writing as significant. In fact, the inscription presents an exegesis before the exegesis and, therefore, microcosmically mirrors the macrostructure of the whole scene.

20 Wandhoff 2012, 41.

21 Wandhoff 2012, 42. 
Before we take a closer look, a little background may be helpful. Tristan and Iseult were banished from court because they were unable to hide their mutual attraction from Marc. Consequently, he suspends their community of three and lets them leave to live their lives as a couple. After two days, Tristan and Iseult arrive at a cave which Tristan once found while hunting. This cave, the narrator explains, had been hewn into the mountain by giants before the advent of Christianity. The giants went there for privacy and intimacy. The cave is round, large, upright, white, and all-around plain and even. It has a magnificent lock and a marble floor, green like grass. In the middle of this structure, there is a bed,

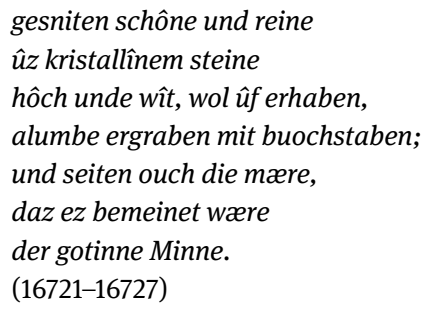

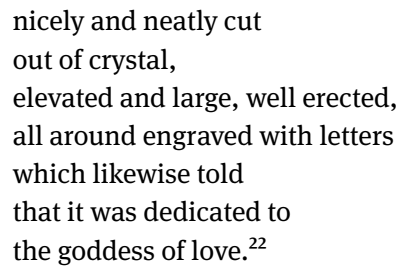

The letters recount what the narrator has already stated. But they also explain to the new inhabitants the purpose of the bed and-since the bed is its centre-the purpose of the cave as a whole. Indeed, the inscription transforms Tristan and Iseult into readers who can give meaning to their new home. But the inscription does not only inform the couple and echo information about the cave's designation. The dedicatory inscription transforms the cave into a semi-sacred space, since it clarifies that the bed is also an altar to Venus. And as an explication of the cave's purpose the inscription therefore also anticipates the later exegesis of the narrator who likewise does what the Tristan and Iseult may do: He reads the cave and inscribes it with meaning.

\section{Maria Krümpelmann and Tamara Ludwig The Perilous Seat}

A wide spectrum of inscribed artefacts appears in the narrative world of the Prosa-Lancelot, a Middle High German translation of the anonymous Old French Lancelot Grail Cycle (thirteenth century). As one of the major sources of the Arthurian Legend, it recounts the story of the rise and fall of King Arthur, the adulterous romance of Lancelot and Guinevere and the quest for the Holy Grail. Particularly curious inscriptions manifest themselves on the so-called Perilous Seat, a hazardous and wondrous object playing a key role in the constitution of the Round Table, around which

22 Gottfried von Straßburg 2004. The translation is mine. 
the king and his knights regularly congregate and take counsel. Throughout the narrative, the general rules of awarding seats at the Round Table undergo meaningful changes. When a recluse questions Iwein about the current fashion of allocating seats, he recalls the old customs under King Uterpandragon where a knight was only invited to sit at the Table when exhibiting an injury on the face (cf. V, 610, 18-29). During Arthur's reign, this custom has been abandoned and the king has made it his personal judgement to grant a seat as an expression of a knight's special worthiness (cf. III, 614,8-14), rendering the table a medium of assembling the best knights. The idea of the Round Table now more than ever highlights the marked absence of hierarchical power structures. As an elevated place with no head, it conceptualises the ideal of chivalric order as a state of unbroken equivalence and unity among its members.

With the arrival of Lancelot, Galahot and Hector at Court, nearly all the seats at the Round Table appear to be occupied for the first time, hinting at the impending start of the Quest for the Holy Grail. However, one empty seat remains, defying the picture of homogeneity: common knowledge at the King's Court has it that one seat at the Round Table, at times referred to as the Perilous Seat (Sorglich Se $\beta$, V, 14,32), at others as the Wondrous Seat (Wunderlich Se $\beta, \mathrm{V}, 154,32$ ) or as the seat "at the very back" (hindersten se $\beta, \mathrm{IV}, 412,25$ ), must remain vacant until the person it was crafted for-its meister (master, V, 14,36)-arrives. The king cannot wield any authority over it; and even Lancelot, who is praised as excelling all the other knights in terms of chivalry and virtue, does not venture to come near it, daring only to sit next to it (cf. IV, 410, 31).

The Perilous Seat's preeminent status becomes brutally apparent when Brumal, an overconfident knight makes the mistake of putting its unavailability to the test. Due to a feud between their respective families, Brumal denounces Lancelot for not having the courage to sit on the Perilous Seat. But, on that very day, a fresh inscription appears on the seat as if by magic, proclaiming Brumal's impending death: Alhie muß off dißem hutigen tag sterben der hochfertig Brumal; und stirbt er nit, so hatt Merlin gelogen in syner prophecye, ("On here the proud Brumal will die today; and if he does not die, Merlin lied in his prophecy”, IV, 410,33-35). In spite of the inscription-or possibly in acceptance of his fate-Brumal sits down on the seat, screams in anguish and is dramatically reduced to ashes by shots of fire falling down on him (cf. IV, 414, 13-27). Whether he is actually killed by a higher power at work in that instant or whether the seat itself is transformed into a sort of vicious "killing device" is left to the reader's imagination here. In any case, King Arthur does not think it necessary to mourn for Brumal's death, although he was acclaimed as an honourable knight earlier by the crowd (cf. IV, 412, 16-19). After all, it was known that the Perilous Seat can only be occupied by one knight. Anyone trespassing this rule must be considered a fool (ein groß dorheit, davon ich noch nye han hören sagen, "the greatest folly I have ever heard of”, IV, 418, 15f.).

Soon afterwards, Lancelot perceives a curious change in the Round Table's condition. When he examines the seats one at a time, he notices that they all suddenly bear name tags: Hie sol der siczen, dort sol der siczen ("Here, this one shall sit, and 
over there that one”, V, 14, 29f.). Whereas a very different inscription appears on the Perilous Seat: Vierhundert jare und vierundfunffczig nach dem das gott gemartelt wart, an dem pfingsttag so sol dieser seß synen meister finden ("454 years after the Passion of Christ, at Pentecost, this seat will find its master”, V, 14, 34-36). By conceptualising the coming of the elected knight as in line with salvation history, the inscription lends to the Round Table's endeavours a Christian legitimacy, reinforcing the Seat's own auratic status.

The new prophecy on the Perilous Seat instantly causes a flurry among the knights. After some hurried calculations, they are sure that the day the inscription is talking about must be today. Instructing the others to cover the words with a silken cloth, Lancelot hides the message from view in order to await the king's arrival. When all the knights are gathered at the Round Table, every seat with the exception of the Perilous Seat is taken once again. In that moment, an old man clad in white leading a red knight by the hand wondrously enters, declaring that he has brought the long awaited knight. After delightedly greeting his guest, Arthur invites the new knight to sit on the only vacant seat-the Perilous Seat. When the silken cloth is lifted off the seat, the knights see that yet another inscription has manifested itself there: Hie ist Galaat seß (“This is Galaad's seat”, V, 22, 27). Rejoicing, the knights of the Round Table know that the knight who will complete the Quest for the Holy Grail has finally arrived!

The various forms of extraordinary writing appearing on the Perilous Seat aptly display how script may intermittently transform a mere household item into an object with striking agency. Within the egalitarian structure of the Round Table, the Perilous Seat acts as a producer of hierarchy. By repeatedly unsettling the chivalric order, it is the seat itself which effectively marks Galaad as the best of all the knights and appoints him as the only one able to conclude the Quest. With the subsequent integration of Galaad into the Round Table, the Perilous Seat returns to its object status and its inscription aligns itself with the others. In the end, it has become a seat like any other.

\section{Ludger Lieb}

\section{The Holy Grail}

At the end of the twelfth century two notions of the Grail are familiar: In Robert de Boron's Joseph d'Arimathie (c. 1190-1200), the "Holy Grail” is the very chalice of the Last Supper in which Joseph, standing under the cross, collected Christ's blood. In his Perceval, le Conte du Graal (c.1190) Chrétien de Troyes on the other hand describes the Grail as a golden dish, preciously decorated but otherwise used as tableware (3220: Un graal), in this case to contain the Host. Wolfram von Eschenbach's version of the Grail distinguishes itself from these two concepts of the sacred vessel. In his Parzival (c.1205), Wolfram, although translating Chrétien's Perceval, turns the Grail into an 
amorphous dinc, daz hiez der Grâl ("thing called the Grail” 235,23) and gives it a number of new features, including the fact that inscriptions appear on it several times. Only with Wolfram does the Grail become a script-bearing artefact. ${ }^{23}$

I would like to emphasise three aspects of Wolfram's approach to the inscribed Grail in the following discussion: a) the materiality, b) the practices and c) the writings.

a) In a single passage of only (approximately) 80 verses $(469,3-471,26)$ Trevrizent, Parzival's uncle, calls the Grail a "stone" 16 times. What is expressed here is, in fact, not so much the material (the mineral substance "stone") as its concreteness (the touchable thing "stone", a kind of "geofact"): The Grail is a thing that is locomobile and not further worked on. The actual materiality of the Grail can only be understood indirectly. Trevrizent reports that already at the fall of Lucifer God sent the so-called neutral angels to the Grail (471,15-22). That must have been shortly before or shortly after the creation of the world, certainly before the creation of humanity. Therefore, the Grail is a divine 'artefact' from the time of creation. It is a thing, the materiality of which cannot possibly be grasped with human terms.

b) Due to this unknown, somewhat peculiar materiality there are also practices connected with the Grail that are rather strange. The Grail, for instance, is carried through the hall of the Grail castle during feasts in a para-religious procession; and the Grail itself decides who is virtuous enough to be allowed to carry it. The Grail provides food and drink at a banquet and shields anyone who looks at it from death for a week. A dove that places a Host on the Grail every Good Friday replenishes its agency. The unmarried ladies and knights at the castle look after and protect the Grail. So carrying, eating and drinking, looking at, looking after and protecting are practices related to the Grail. Finally, there are the practices of writing and reading, which brings me to the next and last point.

c) Writing and reading are unusual here in at least four ways. First of all-as with the writing on the wall in the Book of Daniel-the writer is missing or, at any rate, nobody can see who or what is producing the script. As the writing appears to function magically, one naturally assumes that God, an angel or some higher being is writing on the Grail. Secondly, the writing does not leave any permanent traces on the material; rather, the letters disappear again when the addressees have read them. The narrator emphasises this phenomenon by commenting: die schrift darf niemen danne schaben: / sô man den namen gelesen hât, / vor ir ougen si zergât ("No one needs to scrape the written off: it melts before the eyes after one has read the name [or the words]"). Thirdly, this phenomenon makes it possible to re-write on the artefact several times in the same place. Fourthly, the script

23 Cf. Lieb/Ott 2016, 277f. For further reading, esp. all features of the Grail and practices related to the Grail cf. Bumke 2004 ${ }^{8}$ 135-142, and more generally Mertens 2003. 
consists of the names of those called to the Grail (Knights of the Grail, the King of the Grail) and of instructions for action that apply very specifically to individual situations rather than presenting permanent mandates. The writing on the Grail thus does not correspond at all to a typical inscription on an object, but apparently replaces an oral (monological) communication.

The writing that appears on the Grail is thus a kind of 'remote communication' that uses a medium that has a virtual surface, an interface with a transcendent sphere. For medieval culture, this Grail is sufficiently alien and fascinating at the same time, because it transcends the 'usual' limitation of the written to 'ordinary' materiality and to 'normal' practices of production and reception-and at the same time confirms their validity. The same applies to perhaps the most curious aspect of Wolfram's Grail: The inscribed Grail is itself the subject of another highly unusual inscription, written inme gestirne ("in the stars" 454,23$)^{24}$ and read by a pagan man whose writings were the first to tell of the Grail. They became the source of the source that Wolfram claims inspired his own text. Bound in the imagination to the transcendent and the celestial, as well as to the political and mundane, Wolfram's Grail is thus a worthy contribution to a cabinet of curiosities.

\section{Michael R. Ott}

\section{Epilogue: Making Connections}

Curiosities, assembled within a "cabinet of curiosities", may all look different and miscellaneous, but they have at least one thing in common: they traverse conventional epistemologies, conventional configurations of knowledge and conventional scientific arrangements. Indeed, that is why such objects were assembled in the first place. The above cabinet of strange and unusual narrated inscriptions was certainly established in this manner. And just like the historical Wunderkammern, our cabinet lacks order and taxonomy, challenging us to consider how and why these extraordinary script-bearing artefacts trouble our traditional epistemologies.

Christine Neufeld's comments on the Ship of Faith may give us some important hints. The locomobile inscribed objects on this ship, she explains, "function as object tests that chart narrative trajectories by revealing individual identities, creating relationships, and propelling heroes to their destinies". To me, this idea of narrative trajectories, encapsulated in script-bearing artefacts, is a key argument, connecting several of the curiosities assembled above.

Reading inscribed artefacts as narrative trajectories reveals them to be interfaces that connect things, characters, and futures (which in medieval literature often means

24 Cf. Strohschneider 2014, 42-57. 
destiny) - and the artefacts bear witness to this connection via script. Our curious "talkative things" reveal factual connections and establish knowledge about the underlying structure of a particular story world. In so doing, these script-bearing artefacts traverse different epistemological sections of these medieval story worlds, especially materiality, human and non-human characters, temporality, and space. Take Flore's horse, for example. This marvellous creature reveals Flore's place in the world by virtue of its own outstanding qualities. The inscription publishes, as I have observed, a naturally given fact, a truth traversing human and non-human characters. Or take the Grail, this kind of "remote communication", linking a higher being commanding the past, present and future, to the mortal world. The Grail, as it is fashioned by Wolfram von Eschenbach, furthermore bends the potentials of common, man-made materials and suspends spatial distance as a necessary component of written communication.

Or, as a last example, take the Perilous Seat. Just like Flore's horse and the Grail, the script-bearing seat marks the place of one extraordinary person. And just like the Grail, the inscription evolves, proving their legitimacy and truth and, later, revealing its legitimate owner. Just like the leash in Titurel and the Apple of Discord the seat brings to an end any notion of an open future in favour of destiny, a destiny embodied by the script-bearing artefact. Again, epistemological sections of the story world interlock, notably the temporal structure, the material integrity of a rather ordinary object, as well as the relationship and association of human characters.

Therefore, if we wonder why all these artefacts assembled above do not fit neatly into the other chapter's narrations, we might ask if this is because we have problems grasping the significance of these epistemological anomalies, whose trajectories are all the more difficult to trace because they move off the archival page, beyond pen and parchment.

\section{Works Cited}

\section{Primary Texts}

Albrecht (1955ff.), Der Jüngere Titurel, 4 vols., ed. by Werner Wolf/Kurt Nyholm (Deutsche Texte des Mittelalters), Berlin.

Chrétien de Troyes (1991), Le Roman de Perceval ou Le Conte du Graal. Der Percevalroman oder Die Erzählung vom Gral. Altfranzösisch/Deutsch, ed. and trans. by Felicitas Olef-Krafft, Stuttgart.

Fleck, Konrad (1846), Flore und Blanscheflur, ed. by Emil Sommer (Bibliothek der gesamten deutschen National-Literatur von der ältesten bis auf die neuere Zeit 12), Leipzig/Quedlinburg.

Füetrer, Ulrich (1997), Das Buch der Abenteuer, 2 vols, ed. by Heinz Thoelen/Bernd Bastert (Göppinger Arbeiten zur Germanistik 638), Göppingen.

Gottfried von Straßburg (2004), Tristan, ed. by Karl Marold/Werner Schröder, Berlin/New York. Konrad von Würzburg (1858), Der Trojanische Krieg, ed. by. Adelbert von Keller (Bibliothek des literarischen Vereins in Stuttgart 44), Stuttgart.

Malory, Sir Thomas (1968), Malory Works, ed. by Eugene Vinaver, Oxford. 
Prosalancelot I-V (1995), ed. and trans. by Hans-Hugo Steinhoff (Bibliothek des Mittelalters 14), Frankfurt am Main.

La Queste del Saint Graal (1923), ed. by Albert Pauphilet, Paris.

The Quest of the Holy Grail (1926), ed. by William W. Comfort, London.

Robert de Boron (1995), Joseph d'Arimathie, ed. by Richard O'Gorman (Studies and texts / Pontifical Institute of Mediaeval Studies 120), Toronto.

Wolfram von Eschenbach (2003²), Parzival, ed. by Karl Lachmann, trans. by Peter Knecht, Berlin/ Boston.

Wolfram von Eschenbach (2003), Titurel, ed. by Helmut Brackert and Stephan Fuchs-Jolie, Berlin/ New York.

Wolfram von Eschenbach (2004), Parzival. With Titurel and the Love-Lyrics, trans. by Cyril Edwards (Arthurian Studies), Cambridge.

\section{Secondary Literature}

Bumke, Joachim (20048), Wolfram von Eschenbach (Sammlung Metzler 36), Stuttgart/Weimar.

Cawsey, Kathy (2001), “Merlin's Magical Writing. Writing and the Written Word in Le Morte Darthur and the English Prose Merlin", in: Arthuriana 11 (3), 89-101.

Daston, Lorraine (2004), “Introduction. Speechless”, in: Lorraine Daston (ed.), Things That Talk: Object Lessons from Art and Science, New York, 9-26.

Daston, Lorraine/Park, Katherine (1998), Wonders and the Order of Nature 1150-1750, New York. Kohl, Karl-Heinz (2003), Die Macht der Dinge. Geschichte und Theorie sakraler Objekte, München.

Lieb, Ludger/Ott, Michael R. (2016), "Schnittstellen. Mensch-Artefakt-Interaktionen in deutschsprachigen Texten des 13. Jahrhunderts", in: Friedrich-Emanuel Focken and Michael R. Ott (eds.), Metatexte. Erzählungen von schrifttragenden Artefakten in der alttestamentlichen und mittelalterlichen Literatur (Materiale Textkulturen 15), Berlin/Boston, 265-280.

Quinn, Esther C. (1965), “The Quest of Seth, Solomon's Ship and the Grail”, in: Traditio: Studies in Ancient and Medieval History, Thought, and Religion 21, 185-222.

Macdonald, Sharon (2006), "Collecting Practices", in: Sharon Macdonald (ed.), A Companion to Museum Studies (Blackwell Companions in Cultural Studies 12), Malden, 81-97.

Mertens, Volker (2003), Der Gral, Stuttgart.

Philipowski, Katharina (2009), “We, daz ie man die strangen sach geschribene! Gehörte und gelesene Schrift in Albrechts Jüngerem Titurel”, in: Internationales Archiv für Sozialgeschichte der deutschen Literatur 34 (1), 49-74.

Pomian, Krzysztof (1990), Collectors and Curiosities. Paris and Venice, 1500-1800, trans. by Elizabeth Wiles-Portier, Cambridge.

Strohschneider, Peter (2014), Höfische Textgeschichten. Über Selbstentwürfe vormoderner Literatur (Germanisch-Romanische Monatsschrift. Beiheft 55), Heidelberg.

Tiller, Kenneth (2004), “En-graving Chivalry. Tombs, Burial, and the Ideology of Knighthood in Malory's Tale of King Arthur", in: Arthuriana 14 (2), 37-53.

Volfing, Annette (2007), Medieval Literacy and Textuality in Middle High German. Reading and Writing in Albrecht's Jüngerer Titurel, New York.

Wandhoff, Haiko (2012), "How to Find Love in Literature. Reading Gottfried von Strassburg's Tristan and His Cave of Lovers", In: Visuality and Materiality in the Story of Tristan and Isolde, ed. by Jutta Eming, Ann Marie Rasmussen and Kathryn Starkey, Notre Dame, 41-64.

Zytaruk, Maria (2011), “Cabinets of Curiosities and the Organization of Knowledge”, in: University of Toronto Quarterly 80 (1), 1-23. 